and friends of diverse disciplines and outlook, and added much to the life of the University and of the wider community. While continuing, together with his students, the cytogenetic study of oats and wheat, his published papers of this period and later cover many fields of interest, notably the structure of chromosomes and their behaviour at meiosis, atypical features of cell division in relation to the cancer problem and the role of the nucleus in growth and differentiation.

Huskins was invited to a professorship in botany in the University of Wisconsin in 1945. He left Canada with many regrets, but kept in close contact with colleagues and friends there and with the Royal Society of Canada, of the Biological and Medical Sciences Section of which he was president in 1951 . At Wisconsin he devoted much energy to general questions of education and helped to formulate and put into action the University's programme of integrated liberal studies.

In 1923 Huskins married Margaret Villy, a native of Manchester, who was at that time lecturer in English in the University of Alberta. Her steady wisdom and unusual artistic and spiritual qualities contributed greatly to the delight of their home, always generously open to many students and friends. Her death in March of last year, after a long illness, clouded the closing months of Huskins's life. They are survived by two daughters and a son.

In his scientific approach Huskins combined a mistrust of simplification and generalization with a driving desire to find a pattern in diversity. Never content to isolate a problem, however deeply absorbed in it, he always tried to relate his thoughts and findings not only to neighbouring scientific fields, but also to practical, social and philosophical questions. He was a champion of the exception, and throughout his life his receptive and tenacious mind built up a store of intellectual and spiritual valuables which he sought continuously to set into a meaningful pattern. He had great energy and a taste for the purposeful use of time, effort and material. These characteristics were expressed in a love of physical work (he was skilled in many useful crafts), in quick movements and speech, and in a rich imagination promptly and emphatically expressed. To his students he was a buoyantly enthusiastic and versatile personality and a stimulating friend. $\mathrm{He}$ will be sadly missed for the fire and colour which he lent to all his enterprises.

\section{Prof. W. K. Fisher}

WALter KenRICK Fisher, professor emeritus of zoology at Stanford University, died on November 2 in California. He was born in Ossining, New York, on February 1, 1878, the son of A. K. Fisher, a prominent naturalist and one of the founders of the U.S. Biological Survey. After a boyhood in New York State and Washington, D.C., his entire academic career was associated with Stanford University, from which he graduated in 1901 , with a doctorate in 1906. He was early interested in botany, as well as in art, but turned to zoology as the result of summers as field naturalist with the Biological Survey, and two voyages as assistant on the famous Albatross expeditions, in 1902 and 1904. The wealth of collections from these cruises and other Pacific sources led him into the taxonomy of the echinoderms, in which he soon became a recognized authority.
Prof. Fisher published "Starfishes of the Hawaiian Islands" in 1906, and in 1911 there appeared "Asteroidea of the North Pacific and Adjacent Waters", a monograph of the U.S. National Museum. Part 2 of this appeared in 1928 and Part 3 in 1930, making nearly $a$ thousand pages. In 1940 he published "Asteroidea", based on the "Discovery" Expeditions. These are, however, but the chief monuments of his work. Dozens of smaller papers, not only on echinoderms but also on other invertebrates, attested his wide competence.

$\mathrm{He}$ was a Fellow of the California Academy of Sciences, and was a curator of its collections during 1916-32. He had a continuing interest in ornithology, having been a president of the Cooper Ornithological Society, and an editor of its journal, The Condor.

Appointed assistant professor of zoology at Stanford in 1909, in 1917 Dr. Fisher became resident director of the Hopkins Marine Station, a division of the University, which had just moved to new quarters at Pacific Grove. At first almost alone, later with an increasing resident staff, he studied the rich fauna of the Monterey Bay region, and built up the reputation of the laboratory as a year-round centre of biological and oceanographical investigation. He was an effective teacher, influencing the careers of many students.

After his retirement in 1943, Prof. Fisher found time to develop his artistic ability. He had long illustrated his own scientific papers in beautiful manner, but now he could take up oil painting. Many careful still-lifes and portraits displayed his real talent in this direction : texture and the play of colour on surfaces especially intrigued him. Yet he also continued zoological study, as research associate of the Smithsonian Institution, and was working on collections from that Museum, and naming new species, up to the last week of his life.

In a biological science tending strongly in other directions, Prof. Fisher was admired and respected as a great protagonist of accurate, scholarly taxonomic work. As one of his colleagues recently wrote: "Systematic Zoology has lost one of its best friends, because he combined so many fine qualities with so much zoological knowledge". $\quad$ L. R. BLINKs

\section{Dr. A. L. Hagedoorn}

By the death of Dr. A. L. Hagedoorn, on November 20 , genetics has lost one of its most colourful figures. An iconoclast by nature, he entered with zest into controversy, especially where established notions were the object of attack. Indeed, it was the lure of battle that brought him as an eager recruit into the Mendelian camp in the early days. But argument never soured Hagedoorn; he remained eager, full of wit and zest, always good-tempered and genial, and always ready with help, advice and encouragement.

Hagedoorn was born in Amsterdam in 1885 and studied at the University there for a short while before going to the United States in 1909, where he studied under Loeb at the University of California, obtaining his doctor's degree for a thesis on "The Purely Maternal Characters of the Hybrids produced from Eggs of Strongylocentrotus". He was one of the small band of early Mendelian experimenters, doing pioneer work mainly with mice and to a less extent with rats, guinea pigs and rabbits. He was quick to point out the analogies in the inheritance of coat colours in rodents, though he failed to formulate the generalization which some years later 
Vavilow propounded as the law of homologous variation. He eagerly joined issue in the controversy about Cuénot's yellow mice, which was not cleared up until Little introduced the idea of lethal factors. Likewise he was in the thick of the dispute about the Himalayan rabbit, a perplexing case before the days of multiple allelomorphs. Throughout his life he stoutly defended against all deviationists the presence and absence theory in its original form.

Hagedoorn's real bent lay in the field of applied genetics. On his return from America, he joined the firm of Vilmorin, the leading seedsmen in France. A few years later, in 1914, he was sent to Java by the Dutch Government to organize the fight against rats in that island. He returned to California in 1916, and then after two years in Berlin with Erwin Baur he settled down in Holland at Soesterberg, where he quickly established himself as a consulting geneticist, both for plant and animal breeders. He also taught in the University of Leyden, and became secretary of the Dutch Genetical Society. He was thus most favourably placed between science and practice, and, with a foot in both camps, he became a familiar figure wherever geneticists or practical breeders were gathered together.

$\mathrm{He}$ is best known in Great Britain for his textbook on animal breeding, the tenth edition of which is due to appear in 1954. In 1950 he published a companion text-book on plant breeding, and in 1953, in collaboration with Geoffrey Sykes, he published a book on poultry breeding. His writing is attractive and persuasive, though coloured with an enthusiasm which sometimes got the better of his good judgment. Since 1945 he has been a frequent visitor to Britain, where he lectured to gatherings of live-stock breeders, both of farm animals and of the fancy. His very great knowledge of the practical problems involved, and his very real understanding of the outlook of the practical man, enabled him to talk to breeders in a language they understood. Few geneticists have been as successful as Hagedoorn in conveying to the practical man the importance of Mendelism to the art of breeding.

Michael Pease

\section{Mr. J. D. Griffith Davies, O.B.E.}

A WIDE circle of scientists throughout the world will have learned with regret of the death on December 18 of John David Griffith Davies, who was assistant secretary of the Royal Society during $1937-46$.

He was born on January 19, 1899, and went from Monmouth School to Jesus College, Oxford, after a period of war service during 1916-19. He graduated in the Honours School of Modern History in 1923 and after a few years teaching in school he joined the City of Leeds Education Department in 1926; he was appoirited assistant secretary of the Royal Society in 1937. It was largely during the period in Leeds that he wrote about a dozen books on historical subjects.

Griffith Davies served the Royal .Society under three presidents, Sir William Bragg, Sir Henry Dale and Sir Robert Robinson. With characteristic energy he applied his considerable talents to problems which faced the Society during the period dominated by the threat of war and war itself. He took a leading part in the construction of the Central Scientific Register, which did much to help in the mobilization of British scientific effort. He had to supervise the transfer of the Society's treasures and library to safe quarters. After the War, when the Society again resumed its full scientific activity in peace-time conditions, Griffith Davies was intimately concerned with the organization of the Newton Celebrations and the Royal Society Empire Scientific Conferencetwo events which were outstanding in the revival of Commonwealth and international scientific relations. In 1947 he was made O.B.E.

On his retirement from the Society's service, he endowed the Wilkins Lecture in the history of science, and although his main interests thereafter were centred on his farm in Gloucestershire, he maintained close contact with the Society's affairs.

$\mathrm{He}$ will be remembered with affection by those who came in contact with him in his wide range of interests.

\section{NEWS and VIEWS}

\section{New Year Honours List}

THE list of New Year Honours includes the names of the following men of science and others associated with scientific work :

K.B.E. : Commander Seton S. C. Mitchell, controller of guided weapons and electronics, Ministry of Supply.

Knights : Arthur L. Binns, chief education officer for Lancashire; Prof. Edward C. Dodds, Courtauld professor of biochemistry, University of London; Prof. James Gray, professor of zoology, University of Cambridge, member of the Development Commission; Dr. Edward T. Paris, chief scientific adviser, Home Office; Dr. William G. Radley, engineer-in-chief, Post Office; Dr. Douglas Veale, registrar, University of Oxford.

C.B. : A. T. Barnard, chief superintendent, Royal Ordnance Factories, Woolwich; Dr. J. M. Stagg, principal deputy director, Meteorological Office, Air Ministry.

C.M.G. : R. E. Brook, deputy chairman, Colonial Development Corporation ; Ian Clunies-Ross, chairman, Scientific and Industrial Research Organization,
Commonwealth of Australia; G. S. Dunnett, secretary, Commonwealth Economic Committee; G. Michael Graham, director of fishery research, Ministry of Agriculture and Fisheries ; Colonel H. W. Mulligan, director, West African Institute for Trypanosomiasis Research; A. E. Trotman, member for Agriculture and Natural Resources, Tanganyika.

C.B.E. : Dr. D. A. Allan, director, Royal Scottish Museum; W. Allan, director of agriculture, Mauritius ; Prof. G. D. Allen, professor of statistics, University of London ; H. Cronly, director of veterinary services and animal industry, Uganda; St. J. de H. Elstub, director of the Metal Division, Imperial Chemical Industries, Ltd. ; Prof. T. Ferguson, professor of public health, University of Glasgow; Dr. J. B. Firth, director, North Western Forensic Science Laboratory, Home Office; R. D. Gwyther, senior partner, Coode and Partners, consulting civil engineers, London ; Miss Kathleen M. Kenyon, lecturer in Palestinian archæology, University of London Institute of Archæology; G. J. S. Little, assistant engineer-in-chief, General Post Office; Dr. K. Mellanby, lately principal, University College, Ibadan, Nigeria; J. H. Nicholson, principal, University 